DOI: https://doi.org/10.3126/jbssr.v5i2.35234

\title{
Factors In luencing Investment Decisions in Gold
}

\author{
Bishesh Thapa ${ }^{1}$ \\ Ajay Kumar Shah²
}

Article History
Received 3 Aug 2020
Reviewed 5 Sept 2020
Revised 1 Oct 2020
Plagiarism Checked
9 Nov 2020
Revised 2 Dec 2020

Accepted 21 Dec 2020

\section{Keywords}

advertisement, investment decision, liquidity, secure investment, social status

Journal of Business and Social Sciences Research (ISSN: 25422812). Vol V, No. 2, Dec 2020

\begin{abstract}
The paper aims to evaluate the various factors influencing investment decisions in gold. Six influential factors such as price of gold, secured investment, liquidity need, social status, advertisement and influences and demand of gold were used and their relation with investment decision in gold was tested. The study is based on descriptive research design and uses the primary data obtained by a structured questionnaire for quantitative analysis. Convenient sampling method was used and sample size of 160 respondents was taken from Kathmandu valley. The study uses descriptive statistics, t-test, and correlation to show the important influential variable and relation with investment decision. Among all the influential variables, liquidity need and social status shows the highest mean value which indicates strong agreement towards reason for investing in gold whereas advertisement and influences has lowest agreement. However, when it comes to relationship of different factors with investment decision on gold then, secured investment has the highest correlation value with the investment decision in gold. Moreover, the results showed that there is positive significant relationship between all the contextual variables and investment decision.
\end{abstract}

\section{Introduction and Study Objectives}

Gold has been commonly accepted as a symbol of precious metals since the beginning of human civilization. Gold has contributed considerably to the stability of the international monetary system in the history of the international currencies, and has also been an important financial commodity in the reserves (Chang et al., 2012).

The Bretton Woods system was initiated to bring the balance between the

${ }^{1} \mathrm{Mr}$ Thapa is an MBA graduate of Ace Institute of Management (affiliated to Pokhara University). His email is bsesthapa@gmail.com

${ }^{2} \mathrm{Mr}$. Shah is PhD scholar and faculty at Kathmandu University School of Management, Nepal. He can be contacted at ajay.shah@kusom.edu.np 
fixed exchange rates for the gold standard which was viewed as favourable to a reconsolidation of the global network of trade and finance and increased flexibility under which countries used to preserve and sustain domestic economic and financial stability in the 1930s. In addition to capital controls, the compromise established an adjustable ties system based on the US Dollar which converts to gold at $\$ 35$ per ounce (Bordo, 2017). This compromise had accredited members both the balance of the exchange rate and the independence to hold full employment for their financial authorities

At the start of the 60's, the US dollar vs. gold fixed interest was regarded as overvalued under the Bretton Woods flat rate system. The US President Johnson's investment in the Vietnam War and Great Society boosted economic prosperity in 1968. When the Americans thrived, more dollarpaying goods were imported. Then the US President Nixon imposed a tariff of 10 per cent on imports. However, four months after the Smithsonian agreement, a new exchange rate parity was introduced and the import surcharge was lifted (Irwin, 2013). This had been done to support domestic manufacturing and reduce the trade deficit. Instead, he raised import prices which slowed growth. President Nixon had placed 90-day freezing wage-price limits during his term. Development then slowed even further because U.S. companies were unable to increase prices to stay profitable. Also, as they were not allowed to slash wages, the only way to cut expenses was to lay off employees. Worse still, President Richard Nixon announced that gold or other reserve assets would no longer be redeemable for the US dollar.

The surprise of Nixon ended the Bretton Woods regime, which brought to light a new age in the history of the United States and of the world. This move caused stagflation for a decade. Nixon further devaluated the currency in 1973 allowing a 42-dollar ounce of gold. Although in the late 60 s the dollar battled within parity in Bretton Woods, it marked the collapse of the system. After the Bretton Woods system collapsed, IMF Members have been free to select whatever form of trading transactions they would like (other than including their currency in gold or allowing free flow of money) to link the foreign currency or currency basket, form the monetary union, adopt another country's currency or participate in the currency block (IMF, 2014).

The gold-owning benefits make gold very famous. Gold can be comfortably cashed throughout the world. This is mainly because there is a certain amount of gold because of being an asset. The market of gold not only depends on prices but also on the macroeconomic and financial variables (Kannan \& Dhal, 2008). Over time, gold still has its worth maintained. Additionally, domestic gold prices are closely interconnected with international gold. International gold prices variations have almost the same echo in domestic gold prices (Mishra \& Mohan, 2012). 
This research aims to explore the variables that affect gold investment choices. People continue to invest in gold but for different reasons and their preferences are influenced by different factors. The main objective of the research is to examine the relationship between different factors and investment decision in gold. This study is significant for the gold vendors/dealers who deals in trade of gold because this study will help them to analyse the factors that influence investment decision on gold. This paper might also be beneficial to the policy makers related to the growth of the market in gold and the exchange rate who formulate the policies relating to the gold market. The remainder of the paper is structured: the second section includes review of the literature, the third section then deals with research methodology, the fourth section consists of findings from the study and data interpretation and the fifth section consists of research conclusion.

\section{Literature Review}

Many people tend to buy gold jewellery such as for family weddings, engagements, birthdays and financial gains (Asha \& Christopher, 2014). Also, gold was strongly preferred due to ease at the time of purchase and being highly liquid in comparison to other instruments (Godbole \& Arekar, 2014). Moreover, investors prefer to invest on gold relative to other metals, family and friends influence the decision of investors, while the majority of respondents are people and based on the market price, investors are prepared to invest on gold and willing to invest on gold for the purposes of marriage (Sasidharan, 2015). However, Chitradevi (2017) found the amount of jewellery a woman owns always indicates her status and contributes on her name to the wealthy list. One study found in jewellery purchasing behaviour, advertisement have no significance relationship with the buying pattern of people (Bahadur, Pandey, Pandit, Kandel, \& Thakur, 2019).

Another study found that no relationship is formed between investor age and gold investment attitudes but there is relationship between investor income and gold investment (Benny \& Biju, 2014). A similar study noted the Indian's attitude to gold has changed (more than a status symbol) but given the ever-increasing price, demand for gold has still not plummeted and a comparative analysis of what variables influence the demand for gold in people pursuing real income and investment in gold had also been carried out. The findings were that the demand for gold is the consequence of investment, people's desire for net wealth and the significant socio-economic and cultural patterns (Suresh, 2011).

Parikh and Vaish (2013) found that high-risk investors are more likely to assign and invest in riskiest assets such as stocks, while low-risk investors allocate and invest more in so-called safe assets such as cash and bonds. Similarly, Nawaz and Sudindra (2013) pointed out that the jewellery followed by gold bullions and gold coins is a favourite option for investors in gold investment. Least percent of investors are conscious of gold certificates and futures and mutual fund options and gold. People tend to invest on gold coins because they are readily available and less than a percentage of respondents have moderate losses. Also, Shah 
(2014) concluded that the portfolio risk, rather than being in one form, would be lower and the returns would be higher if the investment is diversified in various forms. Gold genuinely enhances wealth for investors and investors are free to always consider gold and silver in the short-and long-term future of investment as an asset class. Moreover, another study had similar results.

Shobha (2017) indicated that gold investment risk is lower compared to stocks and tickets because daily volatility is lower in gold prices than daily stock and ticket volatility. The finding also showed no importance of education skills as a variable for investors when they decide to invest in gold or not. Whereas, another study found that in the short-run period, there is a unidirectional relationship between Sensex return to gold price return. The reason being, almost all the investors are ready to invest in the stock market instead of the gold market, and they want to speculate stock in a short period. During long-run relationship between gold Price and stock market return were closely associated. The reason being investors are willing to invest in long term benefit-oriented investments (Selvan \& Ram Raj, 2020).

The international market has associated articles relating to the factors influencing investment decisions on gold. Despite the popularity of gold in Nepal, very few research works have been conducted in Nepal relating to the gold market. This research, however, discusses the scenario gap that currently exists and describes the factors influencing investment on gold and the effect of moderating variables on gold investment decisions.

\section{Conceptual Framework}

The conceptual framework of the study is based on the research conducted by Chitradevi (2017) and some of the variable was also used from the research conducted by Godbole and Arekar (2014). Independent variables and moderating variables are taken as a basis from these researches.

Price of Gold is the worth of money that investors pay to invest onto the gold. It includes: Considering gold prices, gold market information and pricing, exchange rate influence and updates about gold price. Secured Investment indicates less risky investment option. It includes price fluctuations, diversification tool, higher secured returns and limited drop in prices. Liquidity Need is commodities that can quickly be turned into cash. It includes: Gold sold in time of urgency and collateral keeping for taking loans. The status or importance of a person with respect to other people within a society is social status. It includes: Fashion accessories, good gift giving instrument and gold seen as a symbol of status. Advertisements and influences are direct mail, telephones, advertising, radio, television and the internet, non-personal and public communication which influences the decision making of any person. This research includes: Print Medias such as newspapers and TV, word of mouth, jewellery fashion shows, social media advertisement and other investor's influences that affect the investment decisions of the investors. Seasonal Demand refers to the year's seasonal fluctuations in production and 
revenue. Seasonal peaks and troughs in production and/or sales will occur for most products. For this research, it includes: marriage ceremony buying, seasonal festivals and purchase in times of parties.

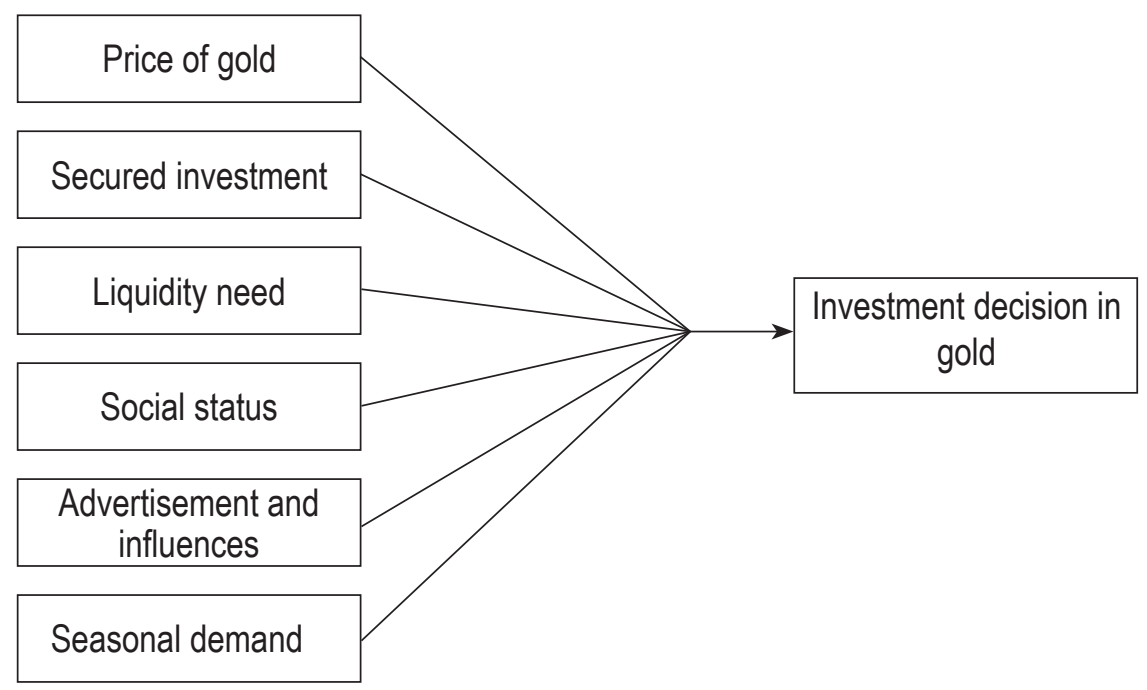

Figure 1: Conceptual Framework

Note. Based on Chitradevi (2017); Godbole and Arekar (2014)

Investment decision in gold indicates decisions made by the investor to invest in gold which varies due to numerous reasons. Whether it's for savings, fashion accessories, gifts, etc. Some of these factors include meeting physical needs, psychological needs and social needs. Many influences include investors thinking, aspirations and preferences.

\section{Research Methods}

\section{Sample and Data Collection Instruments}

All the investors in gold from different age groups, profession and income level residing in the Kathmandu Valley is considered as the population for this research. Initially, the respondents were asked whether they have invested in gold or not. The data had been collected by formulating a questionnaire and distributing it to the respondents who were investing in gold. For getting to the research objectives, 160 questionnaires were distributed and received. Convenience sampling method was used for data collection which is one of the methods under non-probability sampling techniques. Cronbach Alpha Method was used to test the reliability and consistency of the constructs. Taber (2018) indicated that the alpha value of Cronbach 0.70 or higher is the reliability standard of approval and is considered valid. The variables have reliability of at least 0.70 , thus, the variables for the analysis are consistent. 
Table 1

Reliability Test

\begin{tabular}{llll}
\hline Construct & $\begin{array}{l}\text { Minimum } \\
\text { Reliability Index }\end{array}$ & $\begin{array}{l}\text { Cronbach's } \\
\text { Alpha }\end{array}$ & Result \\
\hline Price of gold & 0.60 & 0.70 & Reliable \\
Secured investment & 0.60 & 0.71 & Reliable \\
Liquidity need & 0.60 & 0.71 & Reliable \\
Social status & 0.60 & 0.72 & Reliable \\
Advertisement and influences & 0.60 & 0.79 & Reliable \\
Seasonal demand & 0.60 & 0.71 & Reliable \\
Investment decision & 0.60 & 0.84 & Reliable \\
\hline
\end{tabular}

Note. From Researchers' Calculations based on Survey, 2020

\section{Data Analysis and Discussions}

Both descriptive and inferential analysis are performed. Finally, the results are acquired using the different statistical measures such as mean, correlation and independent $\mathrm{t}$ test.

Table 2

Demographic Profile of the Respondents

\begin{tabular}{|c|c|c|c|}
\hline S.N. & Demographic Variables & $\begin{array}{l}\text { Number of } \\
\text { Respondents } \\
\text { (160) }\end{array}$ & $\begin{array}{l}\text { Percentage of } \\
\text { Respondents } \\
(100 \%)\end{array}$ \\
\hline \multirow[t]{3}{*}{1} & Gender & & \\
\hline & Male & 73 & 45.6 \\
\hline & Female & 87 & 54.4 \\
\hline \multirow[t]{4}{*}{2} & Age Group & & \\
\hline & 15 years to 26 years & 29 & 18.1 \\
\hline & 26 years to 36 Years & 78 & 48.8 \\
\hline & 36 Years and above & 53 & 33.1 \\
\hline \multirow[t]{4}{*}{3} & Monthly Income Level (NPR) & & \\
\hline & Less than 75,000 & 119 & 74.3 \\
\hline & $75,000-100,000$ & 26 & 16.3 \\
\hline & 100,000 and above & 15 & 9.4 \\
\hline \multirow[t]{5}{*}{4} & Profession & & \\
\hline & Self Employed & 41 & 25.6 \\
\hline & Employed in organisation & 44 & 27.5 \\
\hline & Student & 32 & 20.0 \\
\hline & House maker & 43 & 26.9 \\
\hline
\end{tabular}

Note. From Researchers' Calculations based on Survey, 2020 
The demographic profile of the respondents is seen in Table 2. Out of 160 respondents, 73 respondents are male resulting 45.6 per cent and 87 respondents are female resulting 54.4 per cent respectively indicating that women respondents engaged more strongly in this survey. Similarly, 29 respondents are from 15 years to 26 years resulting in 18.1 per cent, 78 respondents are from 26 years to 36 years resulting in 48.8 per cent and 53 respondents are from 36 years and above resulting in 33.1 per cent.

Individual income is the money s/he receives from parents or spouse, in the case of students and house makers who wants to purchase jewellery for their needs. 119 respondents are from less than Rs. 75000 income level resulting 74.3 per cent, 26 respondents are from 75,000-100,000 income level resulting 16.3 per cent and 15 respondents are from 100,000 and above income level resulting 9.4 per cent. Likewise, 41 respondents are self-employed resulting in 25.6 per cent, 44 respondents are employed in organisation resulting in 27.5 per cent, 32 respondents are student resulting in 20 per cent and 43 respondents house maker resulting in 26.9 per cent.

\section{Descriptive Statistics}

The following tables display respondents' response to independent variables, moderating variables and dependent variable.

Table 3

Distribution by Motivation to buy Gold, Periods for Investment on Gold and Investing on Gold on basis of Price Fluctuation

\begin{tabular}{lll} 
S.N. Demographic Variables & $\begin{array}{c}\text { Number of } \\
\text { Respondents } \\
(160)\end{array}$ & $\begin{array}{c}\text { Percentage of } \\
\text { Respondents } \\
(100 \%)\end{array}$ \\
\hline 1 Motivation & 54 & 33.8 \\
$\quad$ Investment purpose & 26 & 16.3 \\
$\quad$ Gift giving & 64 & 40 \\
Fashion Accessories & 16 & 10 \\
Advertisement influence & & \\
2 Periods & 28 & 17.5 \\
Less than 6 months & 45 & 28.1 \\
6 months to 1 year & 54 & 33.8 \\
1 year to 3 years & 33 & 20.6 \\
Above 3 years & & \\
3 Price Fluctuation & 12 & 7.5 \\
When price is increasing & 104 & 65 \\
When price is decreasing & 44 & 27.5 \\
When price is stable & & \\
\hline
\end{tabular}

Note. From Researchers' Calculations based on Survey, 2020 
The distribution of respondents according to motivation to buy gold is shown in the table above. It has been categorised into four sections. Out of 160 respondents, 54 respondents are motivated to buy gold due to investment purpose resulting in 33.8 per cent, 26 respondents are motivated to buy gold due to gift giving purpose resulting in 16.3 per cent, 64 respondents are motivated to buy gold due to fashion accessories purpose resulting in 40 per cent and 16 respondents are motivated to buy gold due to advertisement influence purpose resulting in 10 per cent.

The table also shows the distribution of respondents according to how often they invest on gold. It has been categorised into four sections. Out of 160 respondents, 28 respondents invest on gold in less than 6 months period resulting in 17.5 per cent, 45 respondents invest on gold in 6 months to 1 year period resulting in 28.1 per cent, 54 respondents invest on gold in 1 year to 3 years period resulting in 33.8 per cent and 33 respondents invest in gold in above 3 years period resulting in 20.6 per cent.

The table furthermore shows the distribution of respondents according to when they invest on gold generally. It has been categorised into three sections. Out of 160 respondents, 12 respondents buy gold when price is increasing resulting in 7.5 per cent, 104 respondents invest on gold when price is decreasing resulting in 65 per cent and 44 respondents invest on gold when price is stable in 27.5 per cent.

Table 4

Descriptive Statistics and One Sample t-test

\begin{tabular}{lccccc}
\hline Variables & Mean & $\begin{array}{c}\text { Std. } \\
\text { Deviation }\end{array}$ & $\mathrm{t}$ & Sig. (2-tailed) & Rank \\
\hline Liquidity need & 4.1042 & 0.6995 & 19.964 & 0.000 & 1 \\
Social status & 4.0417 & 0.7001 & 18.819 & 0.000 & 2 \\
Seasonal demand & 3.7896 & 0.6756 & 14.782 & 0.000 & 3 \\
Investment decision & 3.6950 & 0.6928 & 12.689 & 0.000 & 4 \\
Price of gold & 3.6188 & 0.7175 & 10.907 & 0.000 & 5 \\
Secured investment & 3.4656 & 0.6029 & 9.768 & 0.000 & 6 \\
Advertisement and influences & 3.2363 & 0.7432 & 4.021 & 0.000 & 7 \\
\hline
\end{tabular}

Statements from 1 to 5 (5= Strongly Agree, 4=Agree, 3= Neutral, 2= Disagree and 1= Strongly Agree

Note. From Researchers' Calculations based on Survey, 2020

The table 4 shows the responses given by the respondents regarding price of gold, secured investment, liquidity need, social status, advertisement and influences, seasonal demand and investment decision on gold. The table indicates that respondents have mean agreement on all the contextual factors and dependent variable. It can be seen that respondents agree more in considering gold as an instrument for liquidity and less agreement can be seen on advertisement and 
influences on investing in gold.

Table 5

Correlation Analysis

\begin{tabular}{lcc}
\hline Variables & $\begin{array}{c}\text { Correlation } \\
\text { Coefficient }\end{array}$ & p-value \\
\hline Price of gold (X1) & 0.304 & 0.000 \\
Secured investment (X2) & 0.602 & 0.000 \\
Liquidity need (X3) & 0.336 & 0.000 \\
Social status (X4) & 0.296 & 0.000 \\
Advertisement and influences (X5) & 0.404 & 0.000 \\
Seasonal demand (X6) & 0.208 & 0.008 \\
\hline
\end{tabular}

Note. From Researchers' Calculations based on Survey, 2020

Correlation is a bi-variate measurement evaluating the correlation intensity between two variables and the direction of the relationship. The relation between two variables with a single number falling from -1 to +1 is very useful to summarize through correlation.

Table 5 shows the relationship between independent variables and dependent variable which is investment on gold (X7). The correlation coefficient between gold pricing and investment decision and was found to be 0.304 , which is positively correlated. The correlation coefficient between secured investment and investment decision was found to be 0.602 , which is positively correlated and has the highest correlation as compared to other factors. Likewise, the correlation coefficient between liquidity need and investment decision was found to be 0.336 that is positively correlated.

Similarly, the correlation coefficient between social status and investment decision was found to be 0.296 that is positively correlated. Also, the correlation coefficient between advertisement and influence and investment decision was found to be 0.404 , which is positively correlated. Correspondingly, the correlation coefficient between seasonal demand and investment decision was found to be 0.208 , that is positively correlated but has the least correlation compared to other variables.

The p-value recorded for price of gold, secured investment, liquidity need, social status, advertisement and influences and seasonal demand are 0.000 , $0.000,0.000,0.000,0.000$ and 0.008 respectively which is less than the level of significance $(\alpha)=0.05$. This indicates that all independent variables and dependent variable has a significant relationship.

\section{Conclusion and Implications}

On the basis of the mean agreement to the influential variables, the mean value for liquidity is highest as the respondents believe gold can be sold in time of urgency. Second highest agreement is towards social status which indicates 
respondents also believe investing in gold and jewellery gives a kind of social recognition. Respondents believe society value those who wear gold jewellery. The respondents also agree towards considering price of gold before buying and gold as secured investment. Gold being a good diversification tool makes gold as a secured investment. Whereas, respondents slightly agree advertisement and promotion influences little as the mean value is the least. Moreover, the t-value of all the contextual variable is significant.

With the relation to these factors, the correlation coefficient of all influential variables and dependent variable is positively correlated and significant. But when it comes to investment decision in gold, secured investment has the highest correlation as value of gold does not go below certain level that might make the respondents want to invest in gold, followed by advertisement and influences as when investing in gold they might unknowingly get influenced by jewellery fashion shows, advertisements, word of mouth or even other investor's decision. Furthermore, while investing in gold, investors possibly consider liquidity need as it can also be kept as a collateral while taking loans from banks, followed by price of gold, social status and seasonal demand as they may sometimes purchase gold in different occasions, parties and festivals.

The results regarding whether people consider price of gold before investing, gold considered as a secured investment, gold seen as an instrument for liquidity, gold seen as a social status, advertisement and influences on investing on gold and seasonal demand affecting investment decision on gold match with the findings presented in previous studies by mean agreement to these contextual factors.

\section{References}

Asha, K., \& Christopher, S. E. (2014). A study on buying behavior of customers towards branded and non branded gold jewellery with reference to Kanyakumari district. International Journal of Management, 5(10), 105-114.

Bahadur, B., Pandey, A., Pandit, R., Kandel, N., \& Thakur, A. (2019). Research study on gold purchasing behavior of consumers in Nepal. Asian Journal of Education and Social Studies, 3(2), 1-5. doi:10.9734/AJESS/2019/42173

Benny, V., \& Biju, J. M. (2014). Investment attitude in gold. An Investors Perspective, 19(12), 32-36.

Bordo, M. (2017). The operation and demise of the Bretton Woods system: 1958 to 1971. Retrieved from https://voxeu.org/article/operation-and-demise-brettonwoods-system

Chang, C. L., Chang, J. C., \& Huang, Y. W. (2013). Dynamic price integration in the global gold market, The North American Journal of Economics and Finance, 26, 227-235. Retrieved from https://ideas.repec.org/a/eee/ecofin/v26y2013icp227-235.html

Chitradevi, T. (2017). A study on consumer behaviour towards jewellery. International Journal of Applied Research, 3(1), 853-857.

Godbole, S. S., \& Arekar, K. A. (2014). Retail investors and gold buying behaviour:

A perpetual study of Indian retail investors. Sciedu Press, 3(4), 99-104. doi:

10.5430/afr.v3n4p99 
IMF. (2013). The end of Bretton wood system. Retrieved from IMF: https://www.imf.org/ external/about/histend.htm

Irwin, D. A. (2013). The Nixon shock after forty years: the import surcharge revisited. World Trade Review, 12(1), 29-56. doi:10.1017/S1474745612000444

Kannan, R., \& Dhal, S. (2008). India's Demand for gold: Some issues for economic development and macroeconomic policy. Indian Journal of Economics \& Business, 7(1), 107-128.

Mishra, R. N., \& Mohan, G. J. (2012). Gold prices and financial stability in India. Department of Economic and Policy Research, 1-24.

Nawaz, M. N., \& Sudindra, V. R. (2013). Study on various forms of gold investment. Asia Pacific Journal of Research, 2(4).

Parikh, P., \& Vaish, A. (2013). Gold and investor's perspective in different market conditions. Research India Publication, 3(8), 825-834.

Sasidharan, A. (2015). Gold as an investment option: A study on investment pattern of investors in Kerala. International Journal of Management and Commerce Innovations, 3(1), 681-684.

Selvan, D. S., \& Ram Raj, G. (2020). A study on dynamic relationship between Indian gold price and sensex. The Mattingley Publishing Co., 82, 5910-5915.

Shah, C. (2014). Analysis of individual investors' preference and portfolio risk return for gold as an asset class. Journal of General Management Research, 1(2), 1-13.

Shobha, C. V. (2017). A study on gold as a safer investment alternative among small and medium investors with special reference to Kozhikode district. International Journal of Research, 5(11), 27-45. doi: 10.5281/zenodo.1065958

Suresh, A. (2011). A review on gold quest in the investment portfolio by Indian investors. Economic Times.

Taber, K. (2018). The use of Cronbach's Alpha when developing and reporting research instruments in science education. Research in Science Education, 48(1), 1-24. doi:10.1007/s11165-016-9602-2

\section{Funding}

The author received no funding or financial support in carrying out the research.

\section{Conflict of interest}

The authors have no conflict of interest because of their affiliation and other formal positions. 